Numerical Studies in Differential Equations

By Prof. H. Levy and E. A. Baggott. Vol. 1. Pp. viii +238 . (London: Watts and Co., 1934.) 12s. $6 d$. net.

THE teaching of differential equations in English universities usually follows an unsatisfactory middle path. General theory is omitted as too difficult, while numerical methods are considered unworthy of notice. In consequence, the student is made acquainted with only a small number of special types of equation and is left to believe that nothing can be discovered about the solutions of other types. A reading of even the first two chapters of this book by Prof. Levy and Mr. Baggott would alter the outlook of many such students completely. The second chapter, on graphical methods of solution, would form an excellent addendum to a course in curvetracing, the two together being used to illuminate wide tracts of algebra, geometry, and the calculus.

The main portion of the book is concerned with the numerical solutions of ordinary differential equations of the first and higher orders, consideration of partial differential equations being reserved for the second volume. Many methods, some wellknown, some apparently new, are given and their degrees of accuracy are discussed and compared. It is impossible to estimate the value of these methods without long experience in their use, but they appear to be sufficient for most purposes and some of them are of considerable theoretical interest.

There are a few obscurities which might have been removed by careful revision, and a larger number of examples for practice might well have been included. These are minor criticisms, and detract but little from the value of a book which should be in the hands of all who are engaged in research in applied mathematics and of all who are interested in the improvement of mathematical teaching.

\section{Faune de France}

28 : Dipteres (Brachycères), (Muscidae Acalypterae et Scatophagidae). Par E. Seguy. (Federation francaise des Sociétés naturelles : Office central de faunistique.) Pp. iii $+832+27$ plates. (Paris : Paul Lechevalier et fils, 1934.) 300 francs.

THIs systematic survey of the acalyptrate muscid flies testifies to the skill and industry of its author. Numerous keys in the form of tables, short clear descriptions with remarks on differential characters of the families, genera and species, and 903 text figures in addition to 27 plates facilitate, so far as is possible, the identification of these flies. Under each species is a note of the area of distribution and, where known, the period of occurrence of the imago. In those species, the larvæ of which are phytophagous or parasitic, the food-plant or host is stated. In nine pages is a summary of the bionomics of these lower muscids, and at the end of the volume are alphabetical lists of their animal hosts, with their respective parasites and commensals, and of the plants and their respective muscid parasites. A good bibliography and systematic index complete this very satisfactory work.

\section{Wild Flowers of the Great Dominions of the British} Empire

By The Lady Rockley. Pp. xii $+380+32$ plates. (London : Macmillan and Co., Ltd., 1935.) 16s. net.

The non-botanical traveller, who is unable to use a technical flora, often feels in need of a book which will help him to appreciate the vegetation of the various lands he visits and which will indicate what floral treasures are especially worth his notice in particular areas. Lady Rockley, in the present volume, has given the traveller in the British Dominions just such a guide, and her book will undoubtedly appeal to a large public of flower-lovers.

The countries dealt with include Canada and Newfoundland, Australia, New Zealand, South Africa, Rhodesia and Kenya. An immense amount of information has been packed into Lady Rockley's attractively written pages, and the coloured illustra. tions, many of them painted by the author during her travels, with no thought of publication, add greatly to the value of the volume.

\section{Birth Control and its Opponents}

By Frank W. White. Pp. xi+164. (London : John Bale, Sons and Danielsson, Ltd., 1935.) 3s. 6d. net.

IN this little book, the facts of population and overpopulation, and the wastage of human life that results under uncontrolled conditions of mass reproduction, are first marshalled. The regulation of births and limitation of population by artificial methods are then detailed, and the benefits likely to arise therefrom stated. Finally, the arguments of the opposition to artificial methods for the control of pregnancy are set out and examined.

No better brief and popular summary of the subject of birth control could be found than is given here, and as Lord Horder says in his foreword, Dr. White deals patiently and convincingly with the arguments that are advanced against it by a small section of the community. It may be hoped that a growing public opinion will in time convert religious authority, from which the chief opposition at present emanates.

\section{R. T. H.}

\section{A Flower Book for the Pocket}

By Prof. Macgregor Skene. Pp. 380. (London : Oxford University Press, 1935.) 7s. 6d. net.

THIs pocket-book is meant for the layman and also as a first 'flora' for use in schools. 501 flowering plants are illustrated in coloured plates, most of which are reproductions of the paintings by the late Miss C. G. Trower. The rest, together with 28 black and white drawings of grasses, are the work of Miss Ruth Weston. To our knowledge, there is no other book at the price which is so profusely and well illustrated. So far as is possible, technical terms have been avoided. The key includes all British families, and the sequence follows that of the standard British 'floras'. It has been compiled by Prof. Macgregor Skene. Thus, the book has the stamp of authority, is well produced and, unlike many 'floras', is easy to follow. This, together with its low price, should ensure the book of the success that it clearly deserves. 